\title{
Empowering rural women through small scale food processing unit- An approach
}

\author{
GAYATRI BIRADAR AND K. BHAVANI
}

Received: 25.05.2015; Accepted: 27.11.2015

See end of the paper for authors' affiliations

\section{GAYATRI BIRADAR}

Krishi Vigyan Kendra, BIDAR (KARNATAKA) INDIA
ABSTRACT : Agriculture being an important occupation in India, there is huge wastage of perishable agricultural commodities. Despite India being the largest producer of the largest varieties of cereal grains and pulses, the demand for consumption is just growing owing to a large increase in population. Processing of cereal grains and pulses has a bright future ahead. The processing of the food commodities at the village level will not only check the post harvest losses but also provides additional employment (both direct and indirect) to the local people. Bidar district is considered as pulse bowl of Karnataka where in pulses like blackgram, greengram, redgram and bengalgram are major crops comprising 206717 ha area. Hence the main objective of this study was to strengthen the livelihood security by establishing 24 small scale food processing units under NAIP-3 Bidar. The research on small scale food processing unit was conducted by team of NAIP-3, Krishi Vigyan Kendra, Bidar, under an ICAR sponsored project on "Livelihood Security through Resource and Entrepreneurship Management in Bidar district", for 240 selected participants by forming 24 Community Based Organizations consisting of 10 members in each group and introduced mini dal mill, vermicelli machine, chilli pounding machine, flour mill and weighing balance. The project area included 24 selected villages of 4 clusters viz, Aurad, Bhalki, Basavakalyan and Humnabad in Bidar district of Karnataka state. The average income of food processing group was 32,640/month/group/ during season by generating an employment opportunity of 190 man days for 240 members. Thus helping women to empower themselves through group approach.

KEY WORDS: Livelihood security, Food processing, Entrepreneurship, Resources, Management

- HOW TO CITE THIS PAPER : Biradar, Gayatri and Bhavani, K. (2015). Empowering rural women through small scale food processing unit- An approach. Asian J. Home Sci., 10 (2) : 462-465. 